Comparison between the United States and United Kingdom Criticality Safety Personnel Training Program Guidance

A. R. Wysong

July 18,2013 
This document was prepared as an account of work sponsored by an agency of the United States government. Neither the United States government nor Lawrence Livermore National Security, LLC, nor any of their employees makes any warranty, expressed or implied, or assumes any legal liability or responsibility for the accuracy, completeness, or usefulness of any information, apparatus, product, or process disclosed, or represents that its use would not infringe privately owned rights. Reference herein to any specific commercial product, process, or service by trade name, trademark, manufacturer, or otherwise does not necessarily constitute or imply its endorsement, recommendation, or favoring by the United States government or Lawrence Livermore National Security, LLC. The views and opinions of authors expressed herein do not necessarily state or reflect those of the United States government or Lawrence Livermore National Security, LLC, and shall not be used for advertising or product endorsement purposes.

This work performed under the auspices of the U.S. Department of Energy by Lawrence Livermore National Laboratory under Contract DE-AC52-07NA27344. 
July 13, 2012

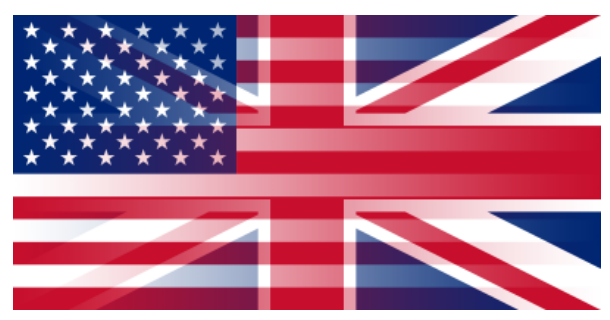

US-UK Mutual Defence Agreement

Joint Working Group 30

Criticality Safety

\section{Comparison between the United States and United Kingdom Criticality Safety Personnel Training Program Guidance}

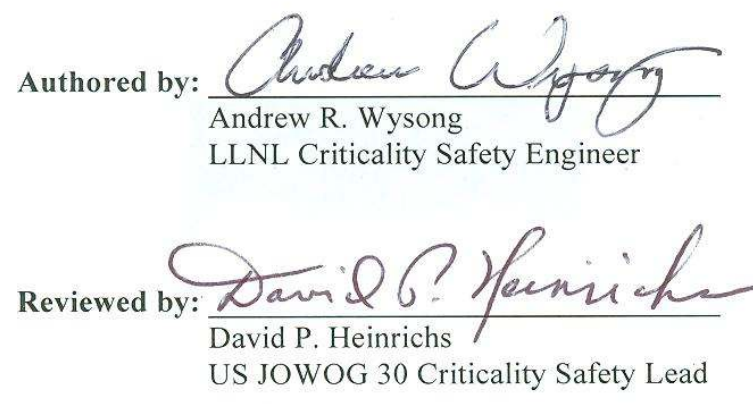

\footnotetext{
Reviewed by:

Nigel P. Tancock

UK JOWOG 30 Criticality Safety Lead
} 


\section{Purpose}

The purpose of this comparison report is to provide an overview of US and UK guidance on criticality safety training program subject matter highlighting similarities and differences to provide a better overall understanding of how the training of criticality safety personnel is accomplished.

\section{Introduction}

The discipline of criticality safety (CS) has been developed in order to maintain safety in operations where significant amounts of fissionable material are to be manipulated. The operation is assessed by an individual or team of CS practitioners and an operational safety envelope is developed. The envelope can consist of limits on materials (i.e. fissionable mass, reflectors, moderators etc.), geometry (i.e. spacing, volume, etc.), and/or proscribed operating procedures which uphold a level of safety margin for personnel and equipment involved. The following report is an overview of the similarities and differences in guidance on training programs for CS personnel at United States (US) and United Kingdom (UK) laboratories.

\section{US Criticality Safety Training Guidance}

The US requirements for "Training and Qualification of Contractor Nuclear Criticality Safety Engineers" in the Department of Energy (DOE) complex are contained within the DOE Standard Guidance for Nuclear Criticality Safety Engineer Training and Qualification. ${ }^{1}$ The guidance is provided to facilitate hiring and maintaining of trained and qualified CS staff within the DOE complex. Within DOE-STD-1135-99 there are ten sections defining the areas of training required to become qualified in the discipline of CS. These sections are:

1. Nuclear Theory

2. Calculational Methods

3. Critical Experiments and Data

4. Rules, Standards, and Guides

5. Nuclear Criticality Safety Evaluations

6. Safety Analysis and Control

7. Criticality Alarm Systems (CAS) and Criticality Detection Systems (CDS)

8. Accountability Practices

9. Hands on Experimental Training

10. Process/Facility Knowledge

In each of these sections a further breakdown of specific skill requirements is listed to further clarify the expectations of the DOE.

Another resource available for training guidance in the US is the national consensus standard ANSI/ANS-8.26-2007² which was created subsequently to DOE-STD-1135-99. The standard supplements the DOE document and provides useful reference material.

\section{UK Criticality Safety Training Guidance}

\footnotetext{
${ }^{1}$ Guidance for Nuclear Criticality Safety Engineer Training and Qualification, DOE-STD-1135-99, Department of Energy, Washington, DC, USA, September 1999 .

${ }^{2}$ Criticality Safety Engineer Training and Qualification Program, ANSI/ANS-8.26-2007, American National Standard, American Nuclear Society, La Grange Park, IL, USA, June 20, 2007.
} 
The UK CS training programs have little official guidance from the Health and Safety Executive (HSE). The guidance document utilized by many nuclear CS programs is The WPC Criticality Safety Competence Framework ${ }^{3}$. The Working Party on Criticality (WPC) is a group of senior CS professionals from a variety of nuclear organisations in the UK. The WPC created the criticality competence framework in response to several issues in the UK nuclear CS community including: the retirement of many senior criticality professionals, decline in number of organisations that were once major contributors to the profession, and increase in number of small firms involved in criticality assessment.

The competence framework is divided into four major sections:

1. Criticality Background Knowledge

2. Criticality Safety Management

3. Criticality Assessment Methods

4. Criticality Safety Assessment Methodologies

In each section specific skills and associated key knowledge/experiences are listed for use as a guide to creation of training programs which encompassed all important areas of CS.

\section{Comparison of Training Requirements}

As expected the US and UK guidance provided for topics in CS training has a good deal of overlap, however there are some subjects unique to each country. The topics and key knowledge/experience have been grouped together under eight main subject areas important to CS. Table 1 displays the data obtained from review of the US and UK CS guidance documents discussed in the preceding sections.

\section{Table 1 - US and UK CS Guidance Comparison}

\begin{tabular}{|l|l|l|l|}
\hline \multicolumn{2}{|c|}{ ACADEMIC } & UK & US \\
\hline \multirow{5}{*}{ Topic } & Key Knowledge/Experience & $\mathrm{X}$ & $\mathrm{X}$ \\
\hline \multirow{5}{*}{$\begin{array}{l}\text { Physics of } \\
\text { Criticality }\end{array}$} & Neutron reactions (fission, absorption, scatter, leakage) & $\mathrm{X}$ & $\mathrm{X}$ \\
\cline { 2 - 4 } & Fission process, fissile isotopes & $\mathrm{X}$ & $\mathrm{X}$ \\
\cline { 2 - 4 } & Differences between fissionable and fissile & $\mathrm{X}$ & $\mathrm{X}$ \\
\cline { 2 - 4 } & Nuclear chain reaction & $\mathrm{X}$ \\
\cline { 2 - 4 } & Neutron balance, k-eff, k-infinity & $\mathrm{X}$ \\
\cline { 2 - 4 } Methods of & Sub-critical, delayed critical, and prompt critical & $\mathrm{X}$ \\
\cline { 2 - 4 } Criticality Control & Reflection, moderation, scattering, shape, interaction & $\mathrm{X}$ \\
\hline & $\begin{array}{l}\text { Familiarity with main factors affecting neutron balance (geometry, mass, } \\
\text { enrichment, concentration, absorption, moderation, reflection, leakage, density, } \\
\text { interaction) }\end{array}$ & $\mathrm{X}$ \\
\cline { 2 - 4 } & $\begin{array}{l}\text { Basic knowledge of implementing controls on main factors: engineered } \\
\text { controls, instrumentation, operational controls }\end{array}$ & $\mathrm{X}$ \\
\cline { 2 - 4 } & $\begin{array}{l}\text { Awareness of the implications of choice of criticality controls (i.e. effects on } \\
\text { ability to demonstrate risks are ALARP, costs of control, impact on timescales, } \\
\text { impact on CID omission argument) }\end{array}$ & $\mathrm{X}$ \\
\hline
\end{tabular}

\footnotetext{
${ }^{3}$ The WPC Criticality Safety Competence Framework, WPC/P243 Issue 1, Working Party on Criticality, UK, November 2008.
} 


\begin{tabular}{|c|c|c|c|}
\hline & $\begin{array}{l}\text { Understanding of criteria used in selection of controlled parameters (i.e. } \\
\text { compliance issues, reliability/simplicity/user-friendly) }\end{array}$ & $\mathrm{x}$ & \\
\hline \multirow{2}{*}{$\begin{array}{l}\text { Anomalies of } \\
\text { Criticality }\end{array}$} & Causes of anomalies & $\mathrm{x}$ & \\
\hline & Most important anomalies & $\mathrm{x}$ & \\
\hline $\begin{array}{l}\text { Reactor Physics } \\
\text { Concepts }\end{array}$ & Understanding the four and six factor formula & $\mathrm{x}$ & \\
\hline \multirow{6}{*}{$\begin{array}{l}\text { Reactor Kinetics } \\
\text { and Transient } \\
\text { Analysis }\end{array}$} & Delayed neutrons & $\mathrm{x}$ & \\
\hline & Beta factors & $\mathrm{x}$ & \\
\hline & In-hour formula & $\mathrm{x}$ & \\
\hline & Feed-back mechanisms & $x$ & \\
\hline & Doppler broadening & $\mathrm{x}$ & \\
\hline & Yield estimation & $x$ & \\
\hline \multicolumn{4}{|c|}{ EXPERIMENTAL } \\
\hline Topic & Key Knowledge/Experience & UK & US \\
\hline \multirow{2}{*}{$\begin{array}{l}\text { Hands-On } \\
\text { Experimental } \\
\text { Training } \\
\end{array}$} & Illustration of basic concepts through hands on training & & $\mathrm{x}$ \\
\hline & Measurement and data analysis relating to criticality safety & & $\mathrm{x}$ \\
\hline \multirow{8}{*}{$\begin{array}{l}\text { Critical } \\
\text { Experiments and } \\
\text { Methods } \\
\text { Validations }\end{array}$} & Importance of validation and how it is achieved & $\mathrm{x}$ & $\mathrm{x}$ \\
\hline & Awareness of experimental facilities and measurement techniques & $\mathrm{x}$ & $\mathrm{x}$ \\
\hline & Sources of experimental data including ICSBEP Handbook & $\mathrm{x}$ & $\mathrm{x}$ \\
\hline & Interpretation and use of validation results to estimate bias and uncertainty & $x$ & $\mathrm{x}$ \\
\hline & Nuclear data evaluation; integral and differential measurement & $\mathrm{x}$ & \\
\hline & Nuclear libraries & $\mathrm{x}$ & \\
\hline & Differences between group and continuous nuclear data & $\mathrm{x}$ & \\
\hline & Pre-processing of group nuclear data & $\mathrm{x}$ & \\
\hline \multicolumn{4}{|c|}{ ASSESSMENT METHODOLOGY } \\
\hline Topic & Key Knowledge/Experience & UK & US \\
\hline \multirow{6}{*}{$\begin{array}{l}\text { Safety } \\
\text { Assessment } \\
\text { Methodologies }\end{array}$} & Optioneering for ALARP & $\mathrm{x}$ & \\
\hline & Defining the scope of the assessment & $\mathrm{x}$ & $\mathrm{x}$ \\
\hline & Identifying hazards & $\mathrm{x}$ & $\mathrm{x}$ \\
\hline & Defining safety criteria & $\mathrm{x}$ & $x$ \\
\hline & Justify \& validate methods & $\mathrm{x}$ & $\mathrm{x}$ \\
\hline & Identify safe envelope & $\mathrm{x}$ & $\mathrm{x}$ \\
\hline \multirow{4}{*}{$\begin{array}{l}\text { Demonstration of } \\
\text { Safety in Normal } \\
\text { and Accident } \\
\text { Conditions }\end{array}$} & Identify safety measures & $x$ & $x$ \\
\hline & Defence-in-depth analysis & $x$ & $x$ \\
\hline & Tolerability of risk analysis & $\mathrm{x}$ & $x$ \\
\hline & Probabilistic risk analysis & $\mathrm{x}$ & $\mathrm{x}$ \\
\hline \multirow{2}{*}{$\begin{array}{l}\text { Principles } \\
\text { Behind } \\
\text { Designation of } \\
\text { Safety Measures }\end{array}$} & Double Contingency Principle approach & $\mathrm{x}$ & $x$ \\
\hline & Design basis assessment & $x$ & $x$ \\
\hline \multirow{7}{*}{$\begin{array}{l}\text { Fault } \\
\text { Identification } \\
\text { Processes }\end{array}$} & Hazop studies & $\mathrm{x}$ & $x$ \\
\hline & Plant walkdowns & $\mathrm{x}$ & $\mathrm{x}$ \\
\hline & Process hazard reviews & $\mathrm{x}$ & $\mathrm{x}$ \\
\hline & Desktop studies & $\mathrm{x}$ & \\
\hline & Design reviews & $x$ & \\
\hline & Standard fault lists associated with physics of criticality & $\mathrm{x}$ & \\
\hline & Limitations of fault identification processes & $\mathrm{x}$ & \\
\hline \multicolumn{4}{|c|}{ ASSESSMENT ANALYSIS } \\
\hline Topic & Key Knowledge/Experience & UK & US \\
\hline \multirow{2}{*}{$\begin{array}{l}\text { Calculational } \\
\text { Methods }\end{array}$} & Boltzman neutron transport equation and terms within it & $\mathrm{x}$ & $\mathrm{x}$ \\
\hline & Deterministic methods for solving transport Equation & $\mathrm{x}$ & $\mathrm{x}$ \\
\hline
\end{tabular}




\begin{tabular}{|c|c|c|c|}
\hline & Monte-Carlo methods for Solving transport Equation & $\mathrm{x}$ & $\mathrm{x}$ \\
\hline \multirow{8}{*}{$\begin{array}{l}\text { Criticality } \\
\text { Computer Codes }\end{array}$} & Methodology supporting Monte-Carlo codes and deterministic codes & $\mathrm{x}$ & $\mathrm{x}$ \\
\hline & Application and limitations of Monte-Carlo and deterministic codes & $\mathrm{x}$ & $\mathrm{x}$ \\
\hline & Physical concept and calculation of number densities & $\mathrm{x}$ & $\mathrm{x}$ \\
\hline & Solution densities & $\mathrm{x}$ & $\mathrm{x}$ \\
\hline & Criticality modelling & $\mathrm{x}$ & $\mathrm{x}$ \\
\hline & Visualize criticality model & $\mathrm{x}$ & $\mathrm{x}$ \\
\hline & Interpret criticality output & $\mathrm{x}$ & $\mathrm{x}$ \\
\hline & Validation and accuracy for major system types & $\mathrm{x}$ & $\mathrm{x}$ \\
\hline \multirow{4}{*}{$\begin{array}{l}\text { Modelling } \\
\text { Complex } \\
\text { Materials }\end{array}$} & Simple or mechanical mixtures & $\mathrm{x}$ & $\mathrm{x}$ \\
\hline & Liquids and solution densities, precipitation, colloids & $\mathrm{x}$ & $\mathrm{x}$ \\
\hline & Phase changes & $x$ & \\
\hline & Alloys & $\mathrm{x}$ & $\mathrm{x}$ \\
\hline \multirow{9}{*}{$\begin{array}{l}\text { Hand Calculation } \\
\text { Methods }\end{array}$} & Kenyon's rules & $\mathrm{x}$ & \\
\hline & Density scaling & $x$ & $x$ \\
\hline & Buckling conversions & $\mathrm{x}$ & $\mathrm{x}$ \\
\hline & Reflector savings & $\mathrm{x}$ & $\mathrm{x}$ \\
\hline & Solid angle & $\mathrm{x}$ & $\mathrm{x}$ \\
\hline & Density analogue & $x$ & $x$ \\
\hline & Surface density & $\mathrm{x}$ & $\mathrm{x}$ \\
\hline & AWE interaction parameter method & $x$ & \\
\hline & Limiting surface density method & $\mathrm{x}$ & $\mathrm{x}$ \\
\hline \multirow{4}{*}{$\begin{array}{l}\text { Material } \\
\text { Accountability }\end{array}$} & Accountability and criticality safety relationship & $x$ & $x$ \\
\hline & Accountability system at facility & $\mathrm{x}$ & $\mathrm{x}$ \\
\hline & Container and material labelling practices & & $x$ \\
\hline & Fissile material area postings & & $\mathrm{x}$ \\
\hline \multirow{4}{*}{ Fissile Assay } & Radiochemical analysis & $\mathrm{x}$ & \\
\hline & Techniques and limitations of gamma and neutron assay & $\mathrm{x}$ & \\
\hline & Limits of detection & $\mathrm{x}$ & \\
\hline & Best-estimates, uncertainties, and derivation of safety margins & $\mathrm{x}$ & $\mathrm{x}$ \\
\hline \multicolumn{4}{|c|}{ RULES, STANDARDS, GUIDES } \\
\hline Topic & Key Knowledge/Experience & UK & US \\
\hline $\begin{array}{l}\text { Regulator } \\
\text { Requirements }\end{array}$ & Overview of regulatory and legal framework & $\mathrm{x}$ & $\mathrm{x}$ \\
\hline $\begin{array}{l}\text { National and } \\
\text { International } \\
\text { Standards }\end{array}$ & Awareness and application & $\mathrm{x}$ & $\mathrm{x}$ \\
\hline $\begin{array}{l}\text { IAEA Transport } \\
\text { Regulations }\end{array}$ & Awareness and application & $\mathrm{x}$ & \\
\hline $\begin{array}{l}\text { Safety Analysis } \\
\text { Report for } \\
\text { Packaging } \\
\text { (SARP) }\end{array}$ & Awareness and application & & $x$ \\
\hline \multirow{3}{*}{$\begin{array}{l}\text { Criticality Safety } \\
\text { Handbooks }\end{array}$} & Awareness of various sources of handbook data & $\mathrm{x}$ & $x$ \\
\hline & Use of handbooks to derive safe limits & $\mathrm{x}$ & $\mathrm{x}$ \\
\hline & Understand limitations on use of handbook data & $\mathrm{x}$ & $\mathrm{x}$ \\
\hline \multicolumn{4}{|c|}{ ALARMS, ACCIDENTS, RESPONSE } \\
\hline Topic & Key Knowledge/Experience & UK & US \\
\hline \multirow{4}{*}{$\begin{array}{l}\text { Criticality Alarm } \\
\text { Systems/ } \\
\text { Criticality } \\
\text { Incident } \\
\text { Detection }\end{array}$} & Reasoning for inclusion as part of criticality emergency plan & $\mathrm{x}$ & $\mathrm{x}$ \\
\hline & Evaluation of detector placement & $\mathrm{x}$ & $\mathrm{x}$ \\
\hline & Familiarity with accident terminology & & $\mathrm{x}$ \\
\hline & General awareness of alarm system and use & & $\mathrm{x}$ \\
\hline
\end{tabular}




\begin{tabular}{|c|c|c|c|}
\hline \multirow[t]{5}{*}{ Systems } & Requirements for testing system & & $\mathrm{x}$ \\
\hline & Exemptions/omission & $\mathrm{x}$ & $\mathrm{x}$ \\
\hline & Emergency response procedures & $\mathrm{x}$ & $\mathrm{x}$ \\
\hline & Fission yield estimation & $\mathrm{x}$ & $\mathrm{x}$ \\
\hline & Dose contours & $x$ & $\mathrm{x}$ \\
\hline \multirow{5}{*}{$\begin{array}{l}\text { Criticality } \\
\text { Accident/Incident } \\
\text { Histories }\end{array}$} & Main types & $\mathrm{x}$ & $\mathrm{x}$ \\
\hline & Common precursors & $x$ & $\mathrm{x}$ \\
\hline & Consequences & $\mathrm{x}$ & $\mathrm{x}$ \\
\hline & Identification of immediate and root causes & $\mathrm{x}$ & $\mathrm{x}$ \\
\hline & Lessons learned & $\mathrm{x}$ & $\mathrm{x}$ \\
\hline \multirow{3}{*}{$\begin{array}{l}\text { Characteristics } \\
\text { of Criticality } \\
\text { Accidents }\end{array}$} & $\begin{array}{l}\text { Key features of kinetic behaviour (fission spikes, quasi steady state, } \\
\text { termination, shutdown) }\end{array}$ & $\mathrm{x}$ & \\
\hline & $\begin{array}{l}\text { Key parameters affecting kinetic behaviour (reactivity insertion, feedback } \\
\text { mechanisms, system type/size) }\end{array}$ & $\mathrm{x}$ & $\mathrm{x}$ \\
\hline & Application to emergency response & $\mathrm{x}$ & $\mathrm{x}$ \\
\hline \multicolumn{4}{|c|}{ PROCESS/FACILITY KNOWLEDGE } \\
\hline Topic & Key Knowledge/Experience & UK & US \\
\hline \multirow{9}{*}{$\begin{array}{l}\text { Criticality } \\
\text { Assessment of } \\
\text { Different Stages } \\
\text { of Facility Life } \\
\text { Cycle }\end{array}$} & Optioneering & $\mathrm{x}$ & \\
\hline & Concept design stage & $\mathrm{x}$ & $\mathrm{x}$ \\
\hline & Operational safety case & $x$ & $x$ \\
\hline & Ad hoc operational support & $\mathrm{x}$ & $\mathrm{x}$ \\
\hline & Periodic review & $\mathrm{x}$ & $\mathrm{x}$ \\
\hline & Plant modification & $\mathrm{x}$ & $\mathrm{x}$ \\
\hline & Ageing/history & $\mathrm{x}$ & $\mathrm{x}$ \\
\hline & Decommissioning & $x$ & $\mathrm{x}$ \\
\hline & Waste retrieval, storage, transport \& disposal & $\mathrm{x}$ & $\mathrm{x}$ \\
\hline \multirow{3}{*}{$\begin{array}{l}\text { Interpretation of } \\
\text { Engineering } \\
\text { Drawings }\end{array}$} & Read and understand engineering drawings & $x$ & \\
\hline & Construct a criticality model from engineering drawings & $\mathrm{x}$ & \\
\hline & Understand a process from flow diagrams & $\mathrm{x}$ & \\
\hline \multirow{7}{*}{$\begin{array}{l}\text { Waste and Long- } \\
\text { Term } \\
\text { Storage/Disposal }\end{array}$} & "Risk-Informed" approach to assessment of waste & $x$ & \\
\hline & Need to balance competing risks and optimize overall risk & $x$ & \\
\hline & Importance of waste characterization & $\mathrm{x}$ & \\
\hline & Band Method for retrieval and long-term storage & $\mathrm{x}$ & \\
\hline & RWMD Operational and post-closure methodologies & $\mathrm{x}$ & \\
\hline & Best practicable environmental option methodology & $\mathrm{x}$ & \\
\hline & Limitations imposed by transport regulations & $\mathrm{x}$ & \\
\hline \multicolumn{4}{|c|}{ SPECIAL CONCERNS } \\
\hline Topic & Key Knowledge/Experience & UK & US \\
\hline \multirow{2}{*}{ Burn-Up Credit } & Practical applications of burn-up credit & $\mathrm{x}$ & \\
\hline & Basis of methodology for BUC & $x$ & \\
\hline \multirow{5}{*}{$\begin{array}{l}\text { Special Materials } \\
\text { (i.e. MOX and } \\
\text { Exotic Nuclides) }\end{array}$} & Validation issues for these systems & $\mathrm{x}$ & \\
\hline & Isotopic approximations for MOX and $\mathrm{Pu}$ & $x$ & \\
\hline & Derivation of densities of MOX materials & $\mathrm{x}$ & \\
\hline & Criticality hazards associated with MOX & $x$ & \\
\hline & Criticality controls in MOX facilities & $\mathrm{X}$ & \\
\hline
\end{tabular}

\section{Unique Guidance Subjects}

The US and UK guidance on CS training includes a number of key knowledge/experience subjects that are unique to either country. A small number of differences between CS training guidance can be attributed to regulatory system and/or organizational discrepancies between the US and UK. For 
example, the subjects of ALARP and Optioneering arise out of the need to satisfy UK Health and Safety Executive regulations found in Safety Assessment Principles for Nuclear Installations ${ }^{4}$. The UK regulations also increase the time and effort spent on fault analysis training as probabilistic risk assessment (PRA) and other risk quantification techniques can be employed. While these topics are included in US training programs, the topic is discussed at a cursory level as the use of risk quantification is rarely required in an evaluation.

An example of organizational difference that creates disparity in guidance relates to the maintenance and testing of criticality alarm systems. In the US these responsibilities lie within the purview of the CS program. Conversely, in the UK these functions generally reside within the Radiological Instrumentation organization and thus are not part of a CS training program.

Many differences in the CS training guidance cannot be attributed to regulatory systems or organizational discrepancies. These subjects are listed below:

UK: Implications of Controls, Nuclear Data, Engineering Drawings, Reactor Physics, Reactor Kinetics and Transients, Fissile Assay Methods, Waste and Long Term Disposal, Burn-Up Credit, MOX

US: $\quad$ Hands-On Training, Container Labelling \& Postings

While the US and UK guidance on CS training may not specifically call out the above subjects, this does not prevent many of the respective facilities from covering the topic in their training programs. For example, criticality assessors from the UK routinely attend the Training Assembly for Criticality Safety Hands-On course offered in the US. And in many US CS programs, MOX, Long Term Disposal, and other facility specific disciplines are included as general CS training. Several of the unique training subjects have been identified as best practice subject additions to training programs and are discussed further in the following section.

\section{Best Practices}

\section{Training Subject Additions}

There are a few training subjects unique to the UK or US that would increase the competency and efficiency of CS staff in both countries if included in CS training programs. Implications of Controls, Engineering Drawings, and Nuclear Data, currently unique to the UK training guidance, would add value in US training programs. The subject of Implications of Controls refers to the effects that a criticality control will have on operations and personnel working within the affected safety envelope. CS professionals may be unaware of slowdowns in operations due to a criticality control because of the tendency to focus solely on safety margin. Additionally, ignoring implications of controls on interconnected processes can cause unforeseen negative impacts on safety outside the boundary of the specific operation being analyzed.

The understanding of engineering drawings allows for more efficient and accurate assumptions to be formulated in the fault identification process. Engineering drawings are commonly used in computer modelling and reactivity calculation where accuracy is a key factor in determining a credible safety margin.

${ }^{4}$ Safety Assessment Principles for Nuclear Facilities, Health and Safety Executive, Merseyside, UK, 2006. 
A CS professional's ability to understand the validity, precision, and accuracy of nuclear data is another important component of the utilization of computer simulations for reactivity calculation. Without at least a fundamental grasp of the way nuclear data is measured and analyzed experimentally, as well as formatted and manipulated in reactivity calculation software, there is a possibility of a user relying on an erroneous result in a safety argument. Although the US training guidance does not specifically call out nuclear data, training material for this topic has been developed in the form of the Nuclear Criticality Safety Engineer Training Module 13, Measurement and Development of Cross Section Sets ${ }^{5}$.

The US training guidance subjects of Hands-On Training and Container Labelling \& Postings would be beneficial inclusions in UK guidance. Hands-On training provides CS professionals a more concrete understanding of the main factors that effect reactivity. More significantly, it makes $\mathrm{CS}$ assessors mindful of the reality of operations involving nuclear material and the constraints and inconveniences encountered by operations staff.

Training on container labelling and postings allows CS professionals to reduce the occurrence of human errors. Although it is omitted from the UK guidance it is reasonable to expect each facility has training to cover the specific procedures and format for labelling containers and creating postings. Even with the assumption of this training subject being covered, it would be beneficial to formally include it in UK training guidance.

\section{Increased Collaboration}

Increased collaboration in the field of training will benefit both US and UK laboratories through access to larger and more diverse training materials and the benchmarking of both countries training guidance to their respective CS programs. A successful example is the US DOE Nuclear Criticality Safety Program Hands-On Training and Education Course, ${ }^{6}$ which provided UK CS professionals opportunity to gain Hands-On experience that does not exist domestically. This cooperation between the US and UK allows for cost sharing and increased awareness and knowledge in the international CS community. Other opportunities for shared training resources and lessons learned in the areas of new facility build, retrofitting of facilities, fabrication of weapons components, and assembly/disassembly of weapons which are areas where the US and UK share common CS concerns.

\section{Conclusion}

The US and UK share many commonalities in training programs, however disparity does exist. Some of the differences are driven by the contrasting regulatory systems while others result from responsibilities placed elsewhere in the business organization. However, there are several unique subject areas apparent in each nation's training guidance which have been identified as best practices for inclusion into CS training guidance in both the US and UK. Furthermore, opportunities exist for additional collaboration between the US and UK in the training of CS staff resulting in an increase of competency and efficiency for all involved personnel and programs.

\footnotetext{
${ }^{5}$ Measurement and Development of Cross Section Sets, NCSET Mod 13, Nuclear Criticality Safety Engineer Training, Nuclear Criticality Safety Program, Department of Energy, http://ncsp.llnl.gov/trainingMain.html.

${ }^{6}$ http://ncsp.llnl.gov/classMain.html
} 